\title{
Spectrum of Emergency Celiotomy at National Institute of Medical Sciences and Research, Jaipur
}

Shashank Singhal $^{1 *}$, Satyendra Pal Singh ${ }^{2}$, Nikhil Mishra ${ }^{3}$

${ }^{1,2}$ Department of General Surgery, NIMS University Rajasthan, Jaipur, India

${ }^{3}$ Department of Pharmacy Practice, NIMS University Rajasthan, Jaipur, India

DOI: $\underline{10.36347 / \text { sasjs.2020.v06i05.008 }}$

| Received: 02.05.2020 | Accepted: 12.05.2020 | Published: 27.05.2020

*Corresponding author: Dr. Shashank Singhal

Abstract

Original Research Article

Emergency Celiotomy is a high risk procedure. This was a hospital-based descriptive study performed in a tertiary care teaching hospital. Celiotomies are more often than not performed in an emergency setting, where these are lifesaving procedures, but because of lack of adequate investigations and pre-operative definitive diagnosis as well as inherent risks of the major surgery and anesthesia, involve a significant risk of morbidity and mortality.The aim of the study is to determine the spectrum of emergency celiotomy. Total number of 265 patients were involved under this study who were admitted to the Department of General Surgery, National Institute of Medical Sciences and Research, Jaipur. After collecting the data, the statistical analysis was performed using the licensed version of statistical package for social science version 17 (SPSS-17) available in the department of Preventive and Social Medicine, NIMSR, Jaipur. Peptic perforation (33\%), acute intestinal obstruction (21\%) and abdominal trauma (21\%) are the common causes of Emergency Celiotomy. In our study, early on the day of admission, is the sheet anchor in saving these patients. $82.3 \%$ cases of our study were operated within 24 hours of admission. Emergency celiotomy carries with it a high mortality $(12.1 \%)$ and this mortality is more common in patients with abdominal trauma, because of associated injuries and delayed presentation.

Keywords: Celiotomy, investigations, morbidity, mortality, abdominal.

Copyright @ 2020: This is an open-access article distributed under the terms of the Creative Commons Attribution license which permits unrestricted use, distribution, and reproduction in any medium for non-commercial use (NonCommercial, or CC-BY-NC) provided the original author and source are credited.

\section{INTRODUCTION}

Celiotomies are one of the most common surgeries performed in the Emergency Operation Theatre. A celiotomy, or a Laparotomy, is a surgical procedure involving an incision through the abdominal wall to gain access into the abdominal cavity [1]. Celiotomies are more often than not performed in an emergency setting, where these are life-saving procedures, but because of lack of adequate investigations and pre-operative definitive diagnosis as well as inherent risks of the major surgery and anesthesia, involve a significant risk of morbidity and mortality [2-4]. Acute mechanical bowel obstruction is a major cause of morbidity and mortality, and is the cause of nearly $15-20 \%$ of admissions for acute abdomen. Nearly $85-90 \%$ of bowel obstruction originates in the small intestine. Conservative management with bowel rest, nasogastric decompression and fluid resuscitation is often successful but nearly $30 \%$ of cases still need operative treatment $[5,6]$. Emergency Celiotomies are associated with a high post-operative complication rate such as wound infection, anastomotic leak, electrolyte imbalance, septicemia, hemorrhage, pulmonary complications etc. There are also late complications such as incisional hernia formation [7, 8]. This study focuses on the etiology behind the Emergency Celiotomy and its outcome, including post-operative complications and mortality, at a tertiary care center, the National Institute of Medical Sciences and Research, Jaipur.

\section{MATERIALS AND METHODS}

This study was conducted in Department of General Surgery, National Institute of Medical Sciences and Research, Jaipur. The duration of the study was eighteen months. Approval to conduct this study was obtained from the Institutional Ethics Committee before starting the study. Total number of 265 patients were involved under this study who were admitted to the Department of General Surgery, National Institute of Medical Sciences and Research, Jaipur. We informed patients about the study, along their caretakers. Only those who agreed to participate were included in the study. A suitable data collection form was degined to collect and document the data. After collecting the data, 
the statistical analysis was performed using the licensed version of statistical package for social science version 17 (SPSS-17) available in the department of Preventive and Social Medicine, NIMSR, Jaipur.

\section{RESULTS}

Out of a total of 265 cases of celiotomy studied, 209 (78.9\%) were due to Acute abdomen, while $56(21.1 \%)$ were due to abdominal trauma.

Table-1: Distribution of the cases according to Age groups

\begin{tabular}{|c|c|c|}
\hline $\begin{array}{c}\text { Age Group } \\
\text { (years) }\end{array}$ & $\begin{array}{c}\text { Number of cases due to Acute } \\
\text { Abdomen (\%age) }\end{array}$ & $\begin{array}{c}\text { Number of cases due to } \\
\text { Trauma (\%age) }\end{array}$ \\
\hline$<\mathbf{2 0}$ & $4(1.9 \%)$ & $2(3.6 \%)$ \\
\hline $\mathbf{2 0 - 4 0}$ & $50(23.9 \%)$ & $12(21.4 \%)$ \\
\hline $\mathbf{4 0 - 6 0}$ & $77(36.8 \%)$ & $18(32.2 \%)$ \\
\hline $\mathbf{6 0 - 8 0}$ & $64(30.6 \%)$ & $17(30.4 \%)$ \\
\hline$>\mathbf{8 0}$ & $14(6.7 \%)$ & $7(12.5 \%)$ \\
\hline TOTAL & $\mathbf{2 0 9}(100 \%)$ & $\mathbf{5 6}(100 \%)$ \\
\hline
\end{tabular}

The mean age of all cases was 53.1 years, with the mean age of patients with acute abdomen being 53 years and the mean age of patients with abdominal trauma being 53.5 years. The difference between the 2 groups was statistically insignificant.

Table-2: Distribution of the cases according to Sex Distribution

\begin{tabular}{|c|c|c|}
\hline Sex & Number of cases due to Acute Abdomen(\%age) & Number of cases due to Trauma(\%age) \\
\hline Male & $141(67.5 \%)$ & $38(67.9 \%)$ \\
\hline Female & $68(32.5 \%)$ & $18(32.1 \%)$ \\
\hline TOTAL & $\mathbf{2 0 9}(100 \%)$ & $\mathbf{5 6}(100 \%)$ \\
\hline
\end{tabular}

The male: female ratio was $2.08: 1$. The male emale ratio in patients with acute abdomen was 2.07:1 and the male: female ratio in patients with abdominal trauma being 2.1:1. The difference between the 2 groups was statistically insignificant, with the p-value being 0.95 .

Table-3: Number of cases with a History of Previous Celiotomy

\begin{tabular}{|c|c|c|}
\hline $\begin{array}{c}\text { History of Previous } \\
\text { Celiotomy }\end{array}$ & $\begin{array}{c}\text { Number of cases due to Acute } \\
\text { Abdomen(\%age) }\end{array}$ & $\begin{array}{c}\text { Number of cases due to } \\
\text { Trauma(\%age) }\end{array}$ \\
\hline Present & $46(22 \%)$ & $0(0 \%)$ \\
\hline Absent & $163(78 \%)$ & $56(100 \%)$ \\
\hline TOTAL & $\mathbf{2 0 9}(100 \%)$ & $\mathbf{5 6}(100 \%)$ \\
\hline
\end{tabular}

Out of a total of 265 cases, 46 cases had a positive history of previous celiotomy. No cases with abdominal trauma had a history of previous celiotomy, while $22 \%$ of case with acute abdomen had a positive history of previous celiotomy.

Table-4: Number of cases with Presence of Comorbidities

\begin{tabular}{|c|c|c|}
\hline $\begin{array}{c}\text { Presence of } \\
\text { Comorbidities }\end{array}$ & $\begin{array}{c}\text { Number of cases due to Acute } \\
\text { Abdomen(\%age) }\end{array}$ & $\begin{array}{c}\text { Number of cases due to } \\
\text { Trauma(\%age) }\end{array}$ \\
\hline Present & $101(48.3 \%)$ & $38(67.9 \%)$ \\
\hline Absent & $108(51.7 \%)$ & $18(32.1 \%)$ \\
\hline TOTAL & $\mathbf{2 0 9}(100 \%)$ & $\mathbf{5 6}(100 \%)$ \\
\hline
\end{tabular}

Above depicted table and figure show the presence or absence of any comorbidities in the study group.

Table-5: Distribution of Cases according to Clinical Features

\begin{tabular}{|c|c|c|c|c|c|c|}
\hline Clinical Feature & \multicolumn{3}{|c|}{$\begin{array}{c}\text { Number of cases due to Acute } \\
\text { Abdomen }\end{array}$} & \multicolumn{3}{c|}{ Number of cases due to Trauma } \\
\hline & Present & Absent & $\%$ age & Present & Absent & $\%$ age \\
\hline Fever & 73 & 136 & 34.9 & 22 & 34 & 39.3 \\
\hline Pallor & 41 & 168 & 19.6 & 11 & 45 & 19.6 \\
\hline Hernia & 19 & 190 & 9.1 & 2 & 54 & 3.6 \\
\hline $\begin{array}{c}\text { Abdominal } \\
\text { Distension }\end{array}$ & 185 & 24 & 88.5 & 47 & 9 & 84 \\
\hline Abdominal Guarding & 158 & 51 & 75.6 & 32 & 24 & 57.1 \\
\hline $\begin{array}{c}\text { Abdominal } \\
\text { Tenderness }\end{array}$ & 201 & 8 & 96.2 & 35 & 21 & 62.5 \\
\hline $\begin{array}{c}\text { Abnormal Digital } \\
\text { Rectal Examination }\end{array}$ & 12 & 197 & 5.7 & 10 & 46 & 17.8 \\
\hline
\end{tabular}


As shown in above figures, there was no statistically significant difference between the two groups on the basis of fever, pallor and abdominal distension; while, abdominal guarding and tenderness were both more in cases with trauma.

Table-7: Distribution of Cases according to Lab Investigations

\begin{tabular}{|c|c|c|c|c|c|c|}
\hline Clinical Feature & \multicolumn{2}{|c|}{$\begin{array}{c}\text { Number of cases due to Acute } \\
\text { Abdomen }\end{array}$} & \multicolumn{3}{c|}{ Number of cases due to Trauma } \\
\hline & Present & Absent & $\%$ age & Present & Absent & $\%$ age \\
\hline Hemoglobin - < 10g/dl & 40 & 169 & 19.1 & 25 & 31 & 44.64 \\
\hline $\begin{array}{c}\text { Total Leucocyte Count - > } \\
\text { 11000/cu mm }\end{array}$ & 135 & 74 & 64.6 & 42 & 14 & 75 \\
\hline $\begin{array}{c}\text { Renal Function Tests - } \\
\text { deranged }\end{array}$ & 70 & 139 & 33.5 & 8 & 48 & 14.3 \\
\hline
\end{tabular}

Increased TLC was seen in majority of cases, whether they were due to acute abdomen or trauma. RFTs were deranged more commonly in patients with acute abdomen, with the difference being statistically significant.

Table-8: Distribution of Cases according to X-Ray findings

\begin{tabular}{|c|c|c|}
\hline X-Ray Findings & $\begin{array}{c}\text { Number of cases due to } \\
\text { Acute Abdomen }(\% \text { age })\end{array}$ & $\begin{array}{c}\text { Number of cases due } \\
\text { to Trauma(\%age) }\end{array}$ \\
\hline Gas Under Diaphragm & $98(46.9 \%)$ & $18(32.1 \%)$ \\
\hline Multiple Fluid Levels & $79(37.8 \%)$ & $0(0 \%)$ \\
\hline Dilated Loops & $10(4.8 \%)$ & $17(30.4 \%)$ \\
\hline Non-specific & $22(10.5 \%)$ & $21(37.5 \%)$ \\
\hline TOTAL & $\mathbf{2 0 9}(100 \%)$ & $\mathbf{5 6}(100 \%)$ \\
\hline
\end{tabular}

Table-9: Distribution of Cases according to USG findings

\begin{tabular}{|c|c|c|c|}
\hline USG Findings & $\begin{array}{c}\text { Number of cases } \\
\text { due to Acute } \\
\text { Abdomen }(\% \text { age })\end{array}$ & $\begin{array}{c}\text { Number of cases } \\
\text { due to Trauma } \\
(\% \text { age })\end{array}$ & $\begin{array}{c}\text { Total Number } \\
\text { of Cases } \\
(\%) \text { age })\end{array}$ \\
\hline Not Done & $81(38.8 \%)$ & $26(46.4 \%)$ & $107(40.4 \%)$ \\
\hline Perforation & $4(1.9 \%)$ & $2(3.6 \%)$ & $6(2.3 \%)$ \\
\hline Obstruction & $72(34.5 \%)$ & $0(0 \%)$ & $72(27.2 \%)$ \\
\hline Appendicitis & $12(5.7 \%)$ & $0(0 \%)$ & $12(4.5 \%)$ \\
\hline Free Fluid & $30(14.3 \%)$ & $14(25 \%)$ & $44(16.6 \%)$ \\
\hline Splenic Injury & $0(0 \%)$ & $6(10.7 \%)$ & $6(2.3 \%)$ \\
\hline NAD & $6(2.9 \%)$ & $3(5.4 \%)$ & $9(3.4 \%)$ \\
\hline Others & $4(1.9 \%)$ & $5(8.9 \%)$ & $9(3.4 \%)$ \\
\hline TOTAL & $\mathbf{2 0 9}(100 \%)$ & $\mathbf{5 6}(100 \%)$ & $\mathbf{2 6 5}(100 \%)$ \\
\hline
\end{tabular}

USG was not done in a total of 107 cases. Features of obstruction was the most common finding, none of the cases in patients with trauma. In patients with abdominal trauma presence of free fluid was the most common finding.

Table-10: Distribution of Cases according to CT findings

\begin{tabular}{|c|c|c|}
\hline CT Findings & $\begin{array}{c}\text { Number of cases due to } \\
\text { Acute Abdomen }(\% \text { age })\end{array}$ & $\begin{array}{c}\text { Number of cases due to } \\
\text { Trauma (\%age) }\end{array}$ \\
\hline Not Done & $172(82.3 \%)$ & $39(69.6 \%)$ \\
\hline Perforation & $6(2.9 \%)$ & $0(0 \%)$ \\
\hline Obstruction & $24(11.5 \%)$ & $0(0 \%)$ \\
\hline Free Fluid & $0(0 \%)$ & $6(10.7 \%)$ \\
\hline Splenic Injury & $0(0 \%)$ & $6(10.7 \%)$ \\
\hline Others & $7(3.4 \%)$ & $5(8.9 \%)$ \\
\hline TOTAL & $\mathbf{2 0 9}(100 \%)$ & $\mathbf{5 6}(100 \%)$ \\
\hline
\end{tabular}

CT was not done in a total of 211 cases. Features of obstruction was the most common finding in patients with acute abdomen. In patients with abdominal trauma, presence of free fluid and splenic trauma were the most common findings. 
Table-11: Distribution of Cases according to Pre-operative Diagnosis

\begin{tabular}{|c|c|c|c|}
\hline $\begin{array}{l}\text { Pre-operative } \\
\text { Diagnosis }\end{array}$ & $\begin{array}{c}\text { Number of cases due } \\
\text { to Acute Abdomen } \\
(\% \text { age })\end{array}$ & $\begin{array}{c}\text { Number of cases } \\
\text { due to Trauma } \\
(\% \text { age })\end{array}$ & $\begin{array}{c}\text { Total number of } \\
\text { cases ( } \% \text { age })\end{array}$ \\
\hline GI Perforation & $107(51.2 \%)$ & $21(37.5 \%)$ & $128(48.3 \%)$ \\
\hline GI Obstruction & $71(34 \%)$ & $0(0 \%)$ & $71(26.8 \%)$ \\
\hline Perforated Appendix & $7(3.4 \%)$ & $0(0 \%)$ & $7(2.6 \%)$ \\
\hline Obstructed Hernia & $12(5.7 \%)$ & $0(0 \%)$ & $12(4.5 \%)$ \\
\hline SAIO & $3(1.4 \%)$ & $0(0 \%)$ & $3(1.1 \%)$ \\
\hline $\begin{array}{c}\text { Intra-Abdominal } \\
\text { Abscess }\end{array}$ & $3(1.4 \%)$ & $0(0 \%)$ & $3(1.1 \%)$ \\
\hline Peritonitis & $2(0.96 \%)$ & $0(0 \%)$ & $2(0.75 \%)$ \\
\hline Penetrating Injury & $0(0 \%)$ & $8(14.3 \%)$ & $8(3 \%)$ \\
\hline Blunt Splenic Injury & $0(0 \%)$ & $6(10.7 \%)$ & $6(2.3 \%)$ \\
\hline Blunt Bladder Injury & $0(0 \%)$ & $3(5.4 \%)$ & $3(1.1 \%)$ \\
\hline BTA & $0(0 \%)$ & $13(23.2 \%)$ & $13(4.9 \%)$ \\
\hline Blunt Liver Injury & $0(0 \%)$ & $3(5.4 \%)$ & $3(1.1 \%)$ \\
\hline Great Vessel Injury & $0(0 \%)$ & $2(3.6 \%)$ & $2(0.75 \%)$ \\
\hline Other & $4(1.9 \%)$ & $0(0 \%)$ & $4(1.5 \%)$ \\
\hline TOTAL & $209(100 \%)$ & $56(100 \%)$ & $265(100 \%)$ \\
\hline
\end{tabular}

Table-13: Distribution of Cases according to Post-Operative Diagnosis

\begin{tabular}{|c|c|c|c|}
\hline Post-operative Diagnosis & $\begin{array}{c}\text { Number of cases due } \\
\text { to Acute Abdomen } \\
\text { (\% age })\end{array}$ & $\begin{array}{c}\text { Number of cases } \\
\text { due to Trauma } \\
\text { (\% age })\end{array}$ & $\begin{array}{c}\text { Total Number } \\
\text { of Cases } \\
(\% \text { age })\end{array}$ \\
\hline Gastric Perforation & $39(18.7 \%)$ & $5(9 \%)$ & $44(16.6 \%)$ \\
\hline Duodenal Perforation & $48(23 \%)$ & $7(12.5 \%)$ & $55(20.8 \%)$ \\
\hline Jejunal/Ileal Perforation & $14(6.7 \%)$ & $7(12.5 \%)$ & $21(7.9 \%)$ \\
\hline Appendicular Perforation & $7(3.4 \%)$ & $0(0 \%)$ & $7(2.6 \%)$ \\
\hline Large Bowel Perforation & $3(1.4 \%)$ & $0(0 \%)$ & $3(1.1 \%)$ \\
\hline Small Bowel Obstruction & $27(12.9 \%)$ & $0(0 \%)$ & $27(10.2 \%)$ \\
\hline Large Bowel Obstruction & $29(13.9 \%)$ & $0(0 \%)$ & $29(10.9 \%)$ \\
\hline Intussusception & $6(2.9 \%)$ & $0(0 \%)$ & $6(2.3 \%)$ \\
\hline Obstructed Hernia & $12(5.7 \%)$ & $0(0 \%)$ & $12(4.5 \%)$ \\
\hline Blunt Liver Injury & $0(0 \%)$ & $3(5.4 \%)$ & $3(1.1 \%)$ \\
\hline Blunt Splenic Injury & $0(0 \%)$ & $6(10.7 \%)$ & $6(2.3 \%)$ \\
\hline Blunt Bowel Injury & $0(0 \%)$ & $13(23.2 \%)$ & $13(4.9 \%)$ \\
\hline Blunt Bladder Injury & $0(0 \%)$ & $3(5.4 \%)$ & $3(1.1 \%)$ \\
\hline Blunt Mesenteric Injury & $0(0 \%)$ & $2(3.6 \%)$ & $2(0.75 \%)$ \\
\hline $\begin{array}{c}\text { Penetrating Small Bowel } \\
\text { Injury }\end{array}$ & $0(0 \%)$ & $5(8.9 \%)$ & $5(1.9 \%)$ \\
\hline $\begin{array}{c}\text { Penetrating Large Bowel } \\
\text { Injury }\end{array}$ & $0(0 \%)$ & $3(5.4 \%)$ & $3(1.1 \%)$ \\
\hline Great Vessel Injury & $0(0 \%)$ & $2(3.6 \%)$ & $2(0.75 \%)$ \\
\hline Appendicular Abscess & $5(2.4 \%)$ & $0(0 \%)$ & $5(1.9 \%)$ \\
\hline Psoas Abscess & $3(1.4 \%)$ & $0(0 \%)$ & $3(1.1 \%)$ \\
\hline Ruptured Liver Abscess & $2(0.96 \%)$ & $0(0 \%)$ & $2(0.75 \%)$ \\
\hline Retroperitoneal Abscess & $1(0.48 \%)$ & $0(0 \%)$ & $1(0.38 \%)$ \\
\hline Perinephric Abscess & $1(0.48 \%)$ & $0(0 \%)$ & $1(0.38 \%)$ \\
\hline Mesenteric Ischemia & $4(1.9 \%)$ & $0(0 \%)$ & $4(1.5 \%)$ \\
\hline Volvulus & $6(2.9 \%)$ & $0(0 \%)$ & $6(2.3 \%)$ \\
\hline $\begin{array}{c}\text { Inoperable Malignant } \\
\text { Lesion }\end{array}$ & $2(0.96 \%)$ & $0(0 \%)$ & $2(0.75 \%)$ \\
\hline TOTAL & $209(100 \%)$ & $56(100 \%)$ & $265(100 \%)$ \\
\hline
\end{tabular}

All 265 cases were broadly classified into having 27 different diagnoses post-operatively and the resulting distribution is depicted in the below shown table and figure. 
The most common diagnosis is peptic perforation (duodenal > gastric) followed by intestinal obstruction. In cases with abdominal trauma, most common diagnosis is bowel injury followed by splenic injury.

Table-14: Distribution of Cases according to Post-operative Complications

\begin{tabular}{|c|c|c|c|}
\hline $\begin{array}{c}\text { Post-operative } \\
\text { Complications }\end{array}$ & $\begin{array}{c}\text { Number of cases } \\
\text { due to Acute } \\
\text { Abdomen } \\
(\% \text { age })\end{array}$ & $\begin{array}{c}\text { Number of } \\
\text { cases due to } \\
\text { Trauma } \\
(\% \text { age })\end{array}$ & $\begin{array}{c}\text { Total } \\
\text { Number of } \\
\text { Cases } \\
\text { (\%)age) }\end{array}$ \\
\hline Wound Infection & $67(32.1 \%)$ & $0(0 \%)$ & $67(25.3 \%)$ \\
\hline Wound Dehiscence & $6(2.9 \%)$ & $3(5.4 \%)$ & $9(3.4 \%)$ \\
\hline Anastomotic Leak & $2(0.96 \%)$ & $0(0 \%)$ & $2(0.75 \%)$ \\
\hline Entra-Abdominal Abscess & $3(1.4 \%)$ & $5(9 \%)$ & $8(3.0 \%)$ \\
\hline Entero-cutaneous Fistula & $3(1.4 \%)$ & $0(0 \%)$ & $3(1.13 \%)$ \\
\hline Others & $10(4.8 \%)$ & $12(21.4 \%)$ & $22(8.3 \%)$ \\
\hline None & $118(56.5 \%)$ & $36(64.3 \%)$ & $154(58.1 \%)$ \\
\hline TOTAL & $\mathbf{2 0 9}(100 \%)$ & $\mathbf{5 6}(100 \%)$ & $\mathbf{2 6 5}(100 \%)$ \\
\hline
\end{tabular}

In most cases, no complication is seen postoperatively. The most common post-operative complication seen is wound infection, which was seen in nearly $25 \%$ cases.

Table-15: Distribution of Cases according to Mortality

\begin{tabular}{|c|c|c|}
\hline & $\begin{array}{c}\text { Number of cases due to } \\
\text { Acute Abdomen }(\% \text { age })\end{array}$ & $\begin{array}{c}\text { Number of cases due } \\
\text { to Trauma (\% age) }\end{array}$ \\
\hline $\begin{array}{c}\text { Mortality (in number of } \\
\text { cases) }\end{array}$ & $17(8.1 \%)$ & $15(26.8 \%)$ \\
\hline Discharged patients & $192(91.9 \%)$ & $41(73.2 \%)$ \\
\hline TOTAL & $\mathbf{2 0 9}(100 \%)$ & $\mathbf{5 6}(100 \%)$ \\
\hline
\end{tabular}

Our study, a total of 32 patients out of 265 cases died during the hospital stay. The distribution of cases according to mortality is depicted above.

\section{DISCUSSIONS}

In this study, the age of the patients varied from 18 to 84 years of age. The majority of the patients were in their $5^{\text {th }}$ or $6^{\text {th }}$ decades of life. This result matches with the study conducted by Gejoe et al. [2] in 2016 where $30.6 \%$ of cases were in the $40-60$ year age group. Also, in the study conducted by Kumar, Haresh et al. [4] in 2018, 33.5\% of all cases were in the 41-60 year age group. In the study conducted by A.Clarke $e t$ al. in UK [7], the mean age of the patients was 63 years with a SD of 18 years. Also a UK based study conducted in 2012 by D.I. Saunders et al. [9] reported maximum number of cases in 60-80 years age group. $\mathrm{K}$. Muqueem et al. [3] also reported that majority of emergency celiotomy patients were in the 21-50 years age group in his study in 2018 in Karnataka. In the study conducted by A.K. Srivastava et al. [10] as well as in the one conducted by Gopalakrishnan et al in 2018 [11], the majority of the cases were in 20-40 years age group. For the patients with abdominal trauma, the majority of the cases in our study were in 40-60 year age group. In the study conducted by Tripathi et al. in 1991 [12], 77\% cases were in the 11-40 years age group. The mean age of the patients with BTA was 32.5 years in the study conducted by Brasel et al. in 1998 [13]. This data can be explained by the fact that people in this age group are generally more active and travel more and are thus prone to RTAs and other occupationrelated hazards. The data obtained in this study is in accordance with the general admission trends of this hospital and the population trend of the district. Nair et al. in 1981 [14] and Vaidyanathan et al. in 1986 [15] studied cases with GI perforation and found most cases to be in $2^{\text {nd }}$ and $3^{\text {rd }}$ decades of their life. In our study, we have 86 female patients out of a total of 265 cases, with a male: female ratio of $2.08: 1$. This male preponderance follows the general admission trend of this hospital. Gejoe et al. [2] reported a M:F ratio of 3.08:1, K. Muqueem et al. [5] reported a ratio of 2.33:1; while H. Kumar et al.[3] reported a M:F ratio of 5.07:1 in a case study of 164 cases. On the other hand, in the UK based study conducted in 2012 by D.I. Saunders et al. [9] reported a M:F ratio of 0.90:1 and A. Clarke et al. noted the M:F ration to be $0.69: 1$. [7] By studying cases of Enteric Perforation, in the study conducted by Singh et al. in 1975 [16], they noted a M:F ratio of 2.7:1 and Mock et al. noted the ration to be 2.4:1 in 1992 [17]. In BTA cases, Branney et al. noted the M:F ratio to be $2.1: 1$ in 1997 [18]. We have found in our study that out of 265 cases, $56(21.13 \%)$ cases were due to abdominal trauma. G. Gejoe et al. [2] also reported similar findings in that they observed that out of 376 , $17.3 \%$ celiotomies were due to abdominal trauma. K. Muqueem et al. [3] reported that in their study $21.2 \%$ of 137 cases were due to abdominal trauma. The history of any previous celiotomy often denotes an ongoing disease process or can be a cause of disease itself. For 
example, post-operative adhesions are a major cause of intestinal obstruction; a history of peptic perforation due to NSAID abuse can predispose a patient to the same disease, especially if a patient does not cease the NSAID overuse. In our study we have found a history of previous celiotomy in $17.6 \%$ of cases. This result matches the value obtained by G. Gejoe et al.[2] in their study in 2016, in which a history of previous celiotomy was found in $18.9 \%$ of 376 cases and also that by $\mathrm{K}$. Muqueem et al. [3] who reported history of previous celiotomy in $13.1 \%$ cases. Post-operative adhesions have been found to be the most common cause of intestinal obstruction by many researchers including DB O'Connor et al.[25], Strickland et al. [19], and Ghosheh et al.[20]. In this study, we have found that of the 46 cases who had a history of a previous celiotomy, 43 had intestinal obstruction due to adhesion formation, while the remaining 3 cases had ileal perforation. For the purpose of this study, comorbidities were defined as any previous illness for which regular medications were being taken by the patient or he/she was on a regular follow-up. Examples include, Diabetes Mellitus, Pulmonary TB, Asthma, COPD, Hypertension and Chronic Liver disease or any substance abuse. This history is very important in the patient care and prior knowledge of any positive history can determine the patient mortality and morbidity. Diabetes leads to poor wound healing and predisposes a patient to wound sepsis as well as anastomotic leak. History of respiratory disease predisposes a patient to postoperative respiratory failure. In this study, comorbidities were present in $52.45 \%$ of all 265 cases. This result is similar to the one obtained by Gejoe et al. [2], who reported that comorbidities were present in $52.9 \%$ (199) of the 376 cases. K. Muqueem et al. [3] reported that substance abuse was present in $37.2 \%$ of all cases and $56.9 \%$ cases had a history of comorbidity. We have found in our study that all of the celiotomies conducted on an emergency basis were necessary. All patients had an underlying pathology that was treated during the celiotomy. Morbidity is slightly increased by a negative celiotomy in blunt abdominal trauma, but with advancements in imaging technologies and ICU care, rates of negative celiotomy have been decreasing[21,22]. As studied by Ross et al.[23] and Dalton et al. [24], surgeon should not hesitate to operate, when in doubt, in acute abdomen or abdominal trauma.

\section{CONCLUSION}

Emergency Celiotomy is a high risk procedure. Peptic perforation (33\%), acute intestinal obstruction $(21 \%)$ and abdominal trauma $(21 \%)$ are the common causes of Emergency Celiotomy. In our study, early on the day of admission, is the sheet anchor in saving these patients. $82.3 \%$ cases of our study were operated within 24 hours of admission. Emergency celiotomy carries with it a high mortality (12.1\%) and this mortality is more common in patients with abdominal trauma, because of associated injuries and delayed presentation.
Conservative management has a definitive role in blunt abdominal trauma.

\section{REFERENCE}

1. E Barrow IASVAPCPDSDM. Current UK practice in emergency laparotomy. Annals of the Royal College of Surgeons of England. 2013 November; 95(8).

2. G. Gejoe IYMR. Emergency Laparotomies at a Tertiary Care Center-a Hospital-Based CrossSectional Study. Indian Journal of Surgery. 2017 June; 79(3).

3. Khalid Muqueem GM. Descriptive Study of the Emergency laparotomies at a Government Teaching Hospital. Journal of Evolution of Medical and Dental Sciences. 2018 March; 7(10).

4. Haresh Kumar MKDKMMDNSC. Study of Clinical Profile of Patients presenting with acute abdomen and surgical interventions done at a district place of Chattisgarh State. Medpulse International Journal of Surgery. 2018 September; $7(3)$.

5. Chiedozi LC, Aboh IQ, Piserchia NE: Mechanical bowel obstruction: Review of 316 cases in Benin City. Am J Surg139:389-393, 1980.

6. Miller G, Boman J, Shrier L. Etiology of small bowel obstruction. Am J Surg180:33-36, 2000.

7. Adrian Clarke HM. Mortality and postoperative care after emergency laparotomy. European Journal of Anesthesia. 2011; 28.

8. Lund H, Kofoed SC, Hillingsø JG, Falck-Larsen C, Svendsen LB. High mortality after emergency room laparotomy in haemodynamically unstable trauma patients. Dan Med Bull. 2011 May 1;58(5):A4275.

9. Saunders D, Murray D, Pichel AC, Varley S, Peden CJ, members of the UK Emergency Laparotomy Network. Variations in mortality after emergency laparotomy: the first report of the UK Emergency Laparotomy Network. British journal of anaesthesia. 2012 Jun 22;109(3):368-75.

10. Srivastava AK, Ghildiyal JP. “Acute Abdomen: A Clinical study on its Pattern and Presentation in a tertiary care Hospital of North India" International journal of scientific research. 2017;6(6): 2277 . 8179

11. Gopalakrishnan V, Anandaraja S, Rengan V, Ravindra C. Comprehensive study of blunt injury abdomen in medical college, Chennai, India. International Surgery Journal. 2018 Nov 28;5(12):3909-12.

12. Tripathi MD, Srivastava RD, Nagar AM, Pratap VK, Dwivedi SC. Blunt abdominal trauma with special reference to early detection of visceral injuries. Indian I surg. 1991;53(5):179-84.

13. Brasel KJ, DeLisle CM, Olson CJ, Borgstrom DC. Splenic injury: trends in evaluation and management. Journal of Trauma and Acute Care Surgery. 1998 Feb 1;44(2):283-6. 
14. Nair SK, Singhal VS, Kumar S. Non-traumatic intestinal perforation. Ind J Surg. 1981 May;43(5):371-78.

15. Vaidyanathan S. Surgical management of typhoid ileal perforation. Ind J Surg. 1986:335-41.

16. Brinster CJ, Singhal S, Lee L, Marshall MB, Kaiser LR, Kucharczuk JC. Evolving options in the management of esophageal perforation. The Annals of thoracic surgery. 2004 Apr 1;77(4):1475-83.

17. Mock CN, Amaral J, Visser LE. Improvement in survival from typhoid ileal perforation. Results of 221 operative cases. Annals of surgery. 1992 Mar;215(3):244.

18. Branney SW, Moore EE, Cantrill SV, Burch JM, Terry SJ. Ultrasound based key clinical pathway reduces the use of hospital resources for the evaluation of blunt abdominal trauma. Journal of Trauma and Acute Care Surgery. 1997 Jun 1;42(6):1086-90.

19. Strickland P, Lourie DJ, Suddleson EA, Blitz JB, Stain SC. Is laparoscopy safe and effective for treatment of acute small-bowel obstruction?. Surgical endoscopy. 1999 Jul 1;13(7):695-8.

20. Ghosheh B, Salameh JR. Laparoscopic approach to acute small bowel obstruction: review of 1061 cases. Surgical endoscopy. 2007 Nov 1;21(11):1945-9.

21. Schnüriger B, Lam L, Inaba K, Kobayashi L, Barbarino R, Demetriades D. Negative laparotomy in trauma: are we getting better?. The American Surgeon. 2012 Nov 1;78(11):1219-23.

22. Ertekin C, Yanar H, Taviloglu K, Güloglu R, Alimoglu O. Unnecessary laparotomy by using physical examination and different diagnostic modalities for penetrating abdominal stab wounds. Emergency medicine journal. 2005 Nov 1;22(11):790-4.

23. Ross SE, Dragon GM, O'Malley KF, Rehm CG. Morbidity of negative coeliotomy in trauma. Injury. 1995 Jul 1;26(6):393-4.

24. Dalton ML, Neely WA. Diagnostic laparotomy for abdominal trauma. A university hospital experience. The American Surgeon. 1986 Jan;52(1):41-3.

25. O'Connor DB, Winter DC. The role of laparoscopy in the management of acute small-bowel obstruction: a review of over 2,000 cases. Surgical endoscopy. 2012 Jan 1;26(1):12-7. 